Prepared for the U.S. Department of Energy

under Contract DE-AC05-76RL01830

\title{
Gas-Phase Treatment of Technetium in the Vadose Zone at the Hanford Site Central Plateau
}

\author{
MJ Truex \\ JE Szecsody \\ L Zhong \\ N Qafoku
}

September 2014

Pacific Northwest

NATIONAL LABORATORY

Proudly Operated by Battelle Since 1965 


\title{
DISCLAIMER
}

This report was prepared as an account of work sponsored by an agency of the United States Government. Neither the United States Government nor any agency thereof, nor Battelle Memorial Institute, nor any of their employees, makes any warranty, express or implied, or assumes any legal liability or responsibility for the accuracy, completeness, or usefulness of any information, apparatus, product, or process disclosed, or represents that its use would not infringe privately owned rights. Reference herein to any specific commercial product, process, or service by trade name, trademark, manufacturer, or otherwise does not necessarily constitute or imply its endorsement, recommendation, or favoring by the United States Government or any agency thereof, or Battelle Memorial Institute. The views and opinions of authors expressed herein do not necessarily state or reflect those of the United States Government or any agency thereof.

\author{
PACIFIC NORTHWEST NATIONAL LABORATORY \\ operated by \\ BATTELLE \\ for the \\ UNITED STATES DEPARTMENT OF ENERGY \\ under Contract DE-AC05-76RL01830
}

Printed in the United States of America
Available to DOE and DOE contractors from the Office of Scientific and Technical Information, P.O. Box 62, Oak Ridge, TN 37831-0062; ph: (865) 576-8401 fax: $(865) 576-5728$
email: reports $a$ adonis.osti.gov
Available to the public from the National Technical Information Service 5301 Shawnee Rd., Alexandria, VA 22312 ph: (800) 553-NTIS (6847)

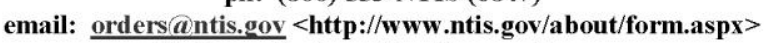 Online ordering: http://www.ntis.gov




\section{Gas-Phase Treatment of Technetium in the Vadose Zone at the Hanford Site Central Plateau}

MJ Truex

JE Szecsody

L Zhong

N Qafoku

September 2014

Prepared for

the U.S. Department of Energy

under Contract DE-AC05-76RL01830

Pacific Northwest National Laboratory

Richland, Washington 99352 



\section{Summary}

Technetium-99 (Tc-99) is present in the vadose zone of the Hanford Central Plateau and is a concern with respect to the protection of groundwater. The persistence, limited natural attenuation mechanisms, and geochemical behavior of Tc-99 in oxic vadose zone environments must be considered in developing effective alternatives for remediation. This report describes a new in situ geochemical manipulation technique for decreasing Tc-99 mobility using a combination of geochemical Tc-99 reduction with hydrogen sulfide gas and induced sediment mineral dissolution with ammonia vapor, which create conditions for deposition of stable precipitates that decrease the mobility of Tc-99. Laboratory experiments were conducted to examine changes in Tc-99 mobility in vadose zone sediment samples to evaluate the effectiveness of the treatment under a variety of operational and sediment conditions.

The laboratory experiments demonstrated a robust treatment approach to decrease the mobility of Tc-99 in the vadose zone at the Hanford Central Plateau using gas-phase amendments. The gas-phase Tc99 treatment was shown to be effective for a variety of operational and site conditions, including 1) sequential and parallel addition of hydrogen sulfide and ammonia gases over a range of treatment gas concentrations, 2) Tc-99 concentrations ranging from 34 to $3800 \mathrm{pCi} / \mathrm{g}, 3)$ soil moisture contents of 1,4 , and $8 \mathrm{wt} \%$, and 4) gas delivery times into the sample ranging from minutes to hours. A large fraction of Tc-99 in treated sediments was also shown be resistant to leaching in saturated soil column tests. These laboratory results suggest that the combined hydrogen sulfide and ammonia gas treatment is a viable candidate for treatment to decrease the mobility of Tc-99 in the vadose zone.

The combined-gas Tc-99 treatment technique is an extension of the ammonia gas treatment for uranium. Previous efforts have examined many aspects of the ammonia treatment process, including key information needed to scale this process to field application. Much of this scale-up information is applicable to field application of the combined hydrogen sulfide and ammonia gas treatment demonstrated in this study to decrease Tc-99 mobility. The information presented herein suggests that, with moderate additional scale-up investigation, the combined-gas Tc-99 treatment could be field tested. Key scale-up elements would include evaluating the fate and transport of hydrogen sulfide gas in the subsurface in the presence of ammonia gas to support determining safe operational conditions for use of hydrogen sulfide. Some additional information on the reaction rates and processes in relation to subsurface $\mathrm{pH}$ conditions and Tc-99 precipitate stability and whether microbial processes interact with these reactions will also be important. For health and safety reasons, it may be important to minimize field collection of gas samples for treatment monitoring. Thus, extension of the electrical resistivity tomography monitoring previously applied for soil desiccation and researched for application to ammonia treatment of uranium should be considered for the combined-gas treatment. Field application will also require engineering of appropriate equipment for safe injection operations. 


\section{Acknowledgments}

This document was prepared by the Deep Vadose Zone- Applied Field Research Initiative at Pacific Northwest National Laboratory. Funding for this work was provided by the U.S. Department of Energy (DOE) Richland Operations Office. The Pacific Northwest National Laboratory is operated by Battelle Memorial Institute for the DOE under Contract DE-AC05-76RL01830. 


\section{Acronyms and Abbreviations}

$\begin{array}{ll}\text { Eh } & \text { oxidation-reduction potential } \\ \mathrm{g} / \mathrm{g} & \text { gram per gram } \\ \mathrm{h} & \text { hour(s) } \\ \mathrm{in} . & \text { inch(es) } \\ \mathrm{M} & \text { molar } \\ \mathrm{mL} / \mathrm{min} & \text { milliliter(s) per minute } \\ \mathrm{mm} & \text { millimeter(s) } \\ \mathrm{pCi} / \mathrm{g} & \text { picocurie(s) per gram } \\ \mathrm{wt} \% & \text { weight percent }\end{array}$





\section{Contents}

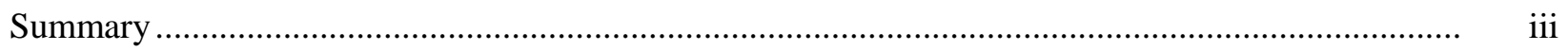

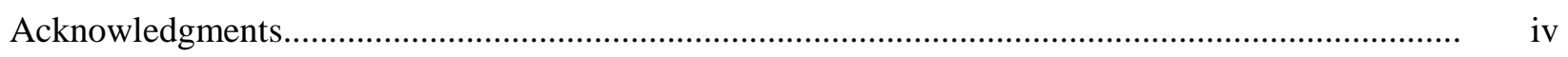

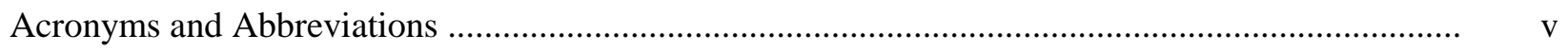

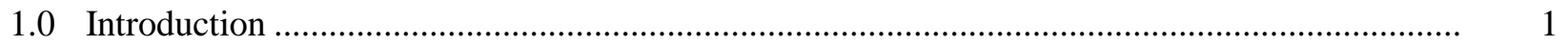

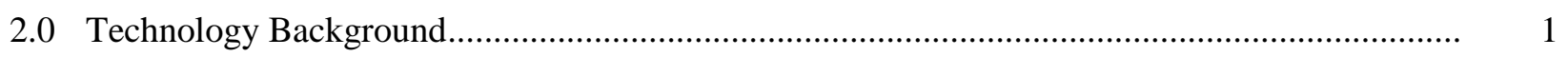

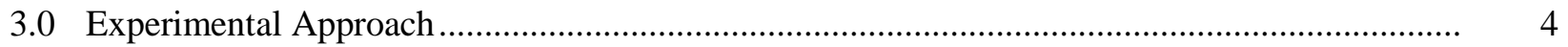

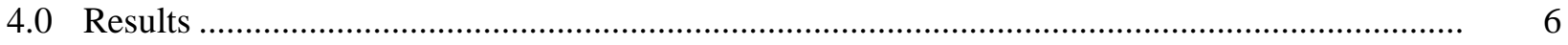

5.0 Conclusions and Implications for Field Testing of the Technology ......................................... 12

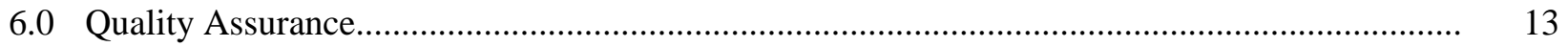

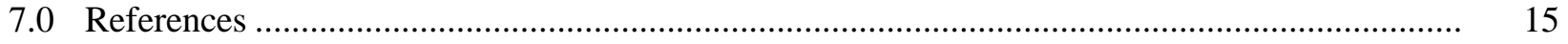




\section{Figures}

1. Overview of the processes that occur with injection of ammonia vapor into an unsaturated uranium-contaminated Hanford sediment.

2. Plot of technetium and iron species as a function of oxidation-reduction potential (Eh) and $\mathrm{pH}$..

3. Sequential extraction data for hydrogen sulfide (A) and ammonia (B) treatment of Tc-99contaminated sediments in comparison to pre-treatment sequential extraction data.

4. Sequential extraction data for combined-gas treatment using sequential (hydrogen sulfide then ammonia) or parallel gas addition over a range of gas concentrations

5. Sequential extraction data for combined-gas treatment using sequential (hydrogen sulfide then ammonia) or parallel gas addition over a range of Tc-99 sediment concentrations

6. Sequential extraction data for combined-gas treatment using sequential (hydrogen sulfide then ammonia) or parallel gas addition for different soil moisture content values range

7. Sequential extraction data for combined-gas treatment using parallel gas addition over a range of minutes to hours for the gas delivery time into the sample.

8. Saturated soil column leaching test results using sediment from the BC Cribs and Trenches site.

\section{Tables}

1. Experimental matrix

2. Sequential extraction solutions 


\subsection{Introduction}

Technetium-99 (Tc-99) is present in the vadose zone of the Hanford Central Plateau and is of concern with respect to the protection of groundwater (DOE/RL 2008). Because Tc-99 is present as the pertechnetate anion in oxic systems such as the Hanford Site subsurface, it is highly mobile in the pore water of the vadose zone and in the groundwater. Radioactive decay of Tc-99 has a long half-life $(2.1 \times$ $10^{5}$ years) and does not functionally contribute to natural attenuation of Tc-99 plumes. However, some Tc-99 physical and geochemical retention has been observed in oxic vadose zone sediments that have not been reduced (Jansik et al. 2014; Szecsody et al. 2010a) and may contribute to natural attenuation in the vadose zone. The $\mathrm{Tc}$ (VII) valence state is dominant in oxic systems (e.g., as the pertechnetate anion) and can be geochemically reduced to less soluble Tc(IV) forms (e.g., Szecsody et al. 2014a). However, geochemical reduction alone is not effective as a remedy for naturally oxic environments because Tc(IV) can be rapidly reoxidized (Burke et al. 2006). The persistence, limited natural attenuation mechanisms, and geochemical behavior of Tc-99 in oxic vadose zone environments must be considered when developing effective alternatives for remediation.

In 2008, the U.S. Department of Energy Richland Operations Office (DOE/RL) initiated a treatability test program to evaluate potential deep vadose zone remedies for protection of groundwater (DOE/RL 2008). As part of this effort, in situ vadose zone remediation approaches are being evaluated as potential options for mitigating the transport of Tc-99 and uranium from the vadose zone to the groundwater. Technologies investigated include soil desiccation (Truex et al. 2012), surface infiltration barriers (Fayer et al. 2010), soil flushing (Truex et al. 2010a), in situ grouting (Truex et al. 2010b), and geochemical manipulation (Szecsody et al. 2010a, b, 2012). Previous geochemical manipulation research conducted as part of this program focused on uranium contamination using gas-phase delivery of amendments. In other related research for saturated aqueous systems, geochemical manipulation with an alkaline amendment, creating alkaline and geochemically reducing conditions, was shown to be effective in decreasing Tc-99 mobility (Szecsody et al. 2014a). However, delivery of aqueous-phase amendments to the vadose zone can be problematic (e.g., Zhong et al. 2009) and gas-phase amendment delivery may be advantageous (Denham et al. 2007; Dresel et al. 2011).

The ensuing sections of this report present technology background and describe a new technique for decreasing Tc-99 mobility using gas-phase amendments that can be distributed in the vadose zone without the negative consequences of using aqueous-phase amendment delivery. The technique uses a combination of geochemical Tc-99 reduction with hydrogen sulfide gas and induced sediment mineral dissolution with ammonia vapor, creating conditions for deposition of stable precipitates that decrease the mobility of Tc-99. The experimental approach describes how laboratory experiments were conducted to examine changes in Tc-99 mobility in vadose zone sediment samples to evaluate the effectiveness of the treatment under a variety of operational and sediment conditions. The report also discusses the laboratory data and results in the context of scaling the process for field application.

\subsection{Technology Background}

The Deep Vadose Zone Treatability Test Plan for the Hanford Central Plateau (DOE/RL 2008) identified gas-phase treatment and geochemical manipulation as potentially effective treatment 
approaches for uranium and Tc-99 in the Hanford Central Plateau vadose zone. Gas-phase geochemical manipulation was initially studied as a potential treatment to address uranium contamination in the vadose zone (Szecsody et al. 2010a). Candidate techniques included geochemical reduction, pH change (acidic and alkaline), and additions of chemicals (phosphate and ferric iron) to form specific precipitates. Reactants were advected into one-dimensional columns packed with uranium-contaminated sediment from the 200 Area of the Hanford Site as a reactive gas (for $\mathrm{CO}_{2}, \mathrm{NH}_{3}, \mathrm{H}_{2} \mathrm{~S}, \mathrm{SO}_{2}$ ), with a $0.1 \%$ water content mist (for $\mathrm{NaOH}, \mathrm{Fe}(\mathrm{III}), \mathrm{HCl}, \mathrm{PO}_{4}$ ) and as a $1 \%$ water content foam (for $\mathrm{PO}_{4}$ ). The study examined the effectiveness of each candidate individually. The wide range of treatments that were evaluated included hydrogen sulfide and ammonia gases. Ammonia was selected as the most promising candidate for further development and field testing.

Additional development of ammonia treatment for uranium has been conducted to improve understanding of the process and prepare for planned field testing (Szecsody et al. 2010a, b, 2012). Figure 1 depicts the three primary elements of uranium treatment by ammonia vapor. When a gas containing ammonia vapor is injected into an unsaturated porous medium, a large percentage of the ammonia partitions into the pore water due to the low Henry's Law constant (a dimensionless value of about $6.5 \times 10^{-4}$ ) of ammonia (Step 1, Figure 1). For instance, a $5 \%$ by volume ammonia vapor produces an equilibrium pore-water concentration of about $3 \mathrm{M}$ ammonia. Through dissociation, this ammonia concentration results in the pore water, starting at around $\mathrm{pH} 8$, rising to above $\mathrm{pH} 11.5$ (Szecsody et al. 2010a, b, 2012). Ion exchange and mineral dissolution (including silicate dissolution) are caused by the caustic pore-water pH (Step 2, Figure 1) (Szecsody et al. 2010a, b, 2012). With high total dissolved solids, precipitates start to form, especially as the $\mathrm{pH}$ is buffered back toward neutral. The precipitates may incorporate uranium (e.g., sodium boltwoodite) or may be compounds such as quartz, chrysotile, calcite, diaspore, and hematite that could coat uranium already precipitated or adsorbed on the sediment surface (Step 3, Figure 1) (Szecsody et al. 2010a, b, 2012). The goal of the dissolution and reprecipitation process is to create uranium precipitates or coatings that render uranium less mobile than before treatment.

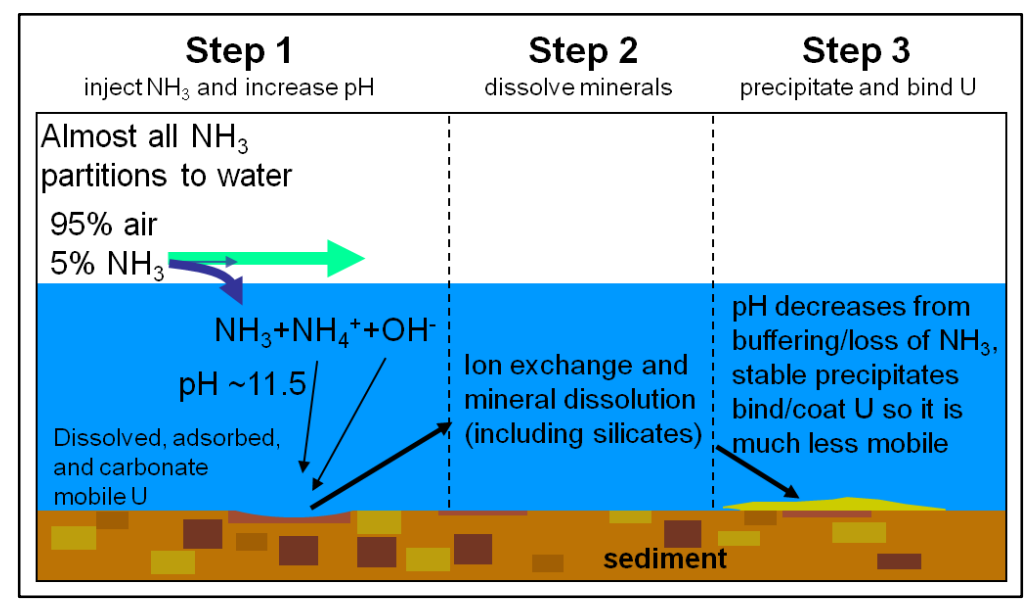

Figure 1. Overview of the processes that occur with injection of ammonia vapor into an unsaturated uranium-contaminated Hanford sediment.

Hydrogen sulfide and ammonia treatment are also candidates for treatment of technetium. As shown in Figure 2, application of hydrogen sulfide gas will lower the oxidation-reduction potential (Eh) of the system and reduce Tc-99, creating conditions suitable for precipitation of reduced Tc-99 compounds. 
However, reoxidation of Tc-99 can readily occur (Zachara et al. 2007) and revert Tc-99 to a soluble form (pertechnetate) as the Eh is increased (see blue arrow in Figure 2). Treatment of Tc-99 with ammonia is not expected to change Tc-99 mobility directly (i.e., Tc-99 remains as pertechnetate in the presence of ammonia, Figure 2). Thus, unless there are indirect effects from ammonia treatment, such as dissolution and subsequent precipitation of other compounds that can coat or bind Tc-99, ammonia would have no impact on Tc-99 concentrations.

While individual gas treatment with hydrogen sulfide or ammonia is not expected to be effective, combined application of these gases may be complementary in terms of removing Tc-99 from the pore water and sequestering it in functionally immobile forms. In the combined-gas approach, the geochemical reduction of Tc-99 by hydrogen sulfide is expected to lead to precipitation of Tc-99 in a reduced form. Aluminosilicate precipitates induced by ammonia treatment may then be deposited and bind or coat existing reduced Tc-99. If this occurs, the Tc-99 would be resistant to reoxidation and prevented from dissolution until these aluminosilicate coatings are dissolved. Because aluminosilicates are stable under the natural geochemical conditions in the Hanford vadose zone, Tc-99 would be functionally immobile with respect to the rate of migration toward the groundwater.

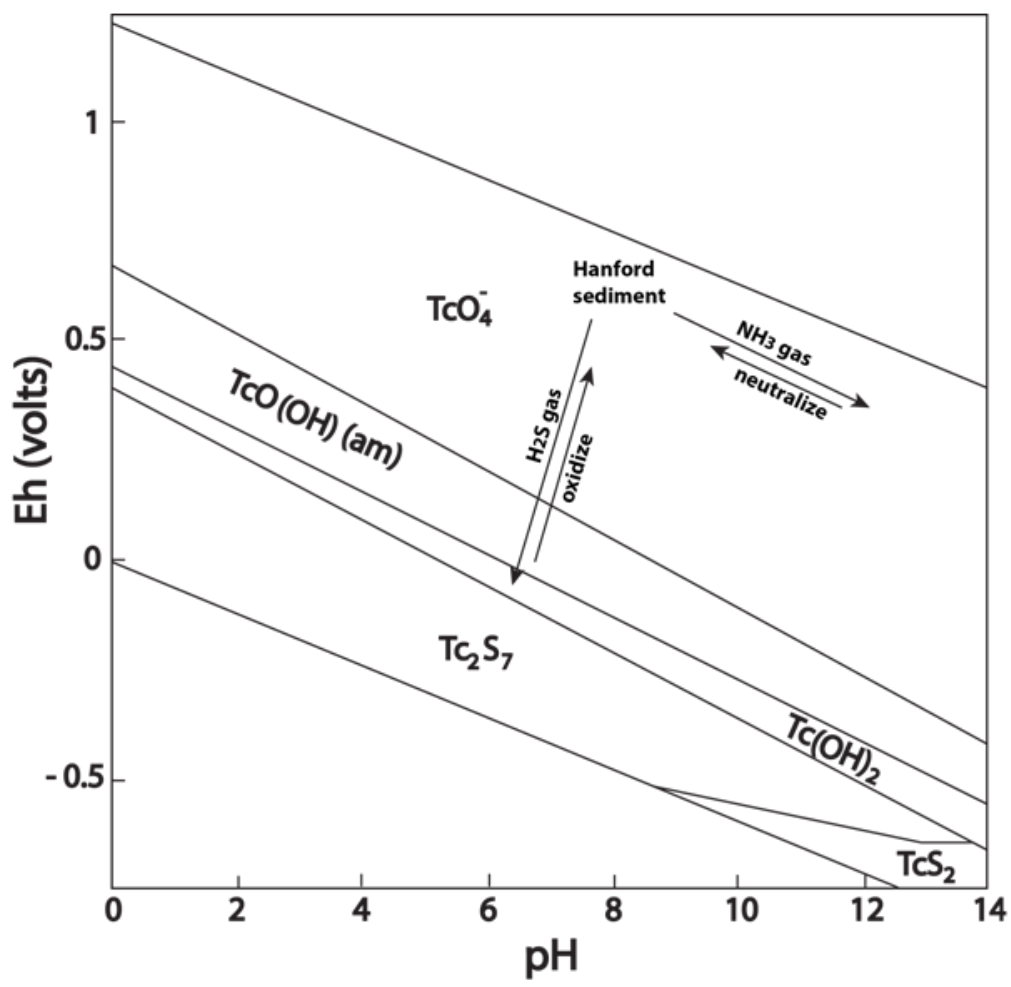

Figure 2. Plot of technetium species as a function of oxidation-reduction potential (Eh) and pH. Nearly vertical arrows show the changes in technetium chemistry caused by oxidation and reduction. Nearly horizontal arrows show the change in $\mathrm{pH}$ induced by ammonia and subsequent neutralization, with no corresponding change in technetium chemistry.

In a previous study (Szecsody et al. 2014a), researchers found that exposure of technetiumcontaminated Hanford sediments to strong alkaline conditions 1) released ferrous iron from biotite dissolution that was capable of reducing technetium and 2) maintained a fraction of the Tc-99 in an immobilized state even when the sediment was oxidized for months. Sediment dissolution and 
subsequent precipitation of aluminosilicates was also observed. After alkaline exposure, and after subsequent exposure of the treated sediments to air for 4 months, X-ray adsorption near-edge structure (XANES) analysis of the sediment surfaces showed that most of the Tc-99 was resistant to leaching and still present in a geochemically reduced form (Szecsody et al. 2014a). These data are interpreted as demonstrating that combined geochemical T-99 reduction and aluminosilicate dissolution and reprecipitation can result in functionally immobile Tc-99 precipitates, consistent with a mechanism of reduced Tc-99 precipitates being coated with low-solubility aluminosilicate precipitates.

\subsection{Experimental Approach}

This section summarizes the experimental approach used to evaluate gas-phase treatment of Tc-99. Additional experimental details are provided in Szecsody et al. (2014b). Sediments for experiments were obtained from borehole grab samples at the 200-BC-1 operable unit (BC Cribs and Trenches site) from boreholes $\mathrm{C} 7534$ and $\mathrm{C} 7540$. Table 1 shows the experimental matrix. Experiments were conducted using 0.75-cm-diameter by 12-cm-long stainless steel columns packed with sediment at specified water contents $(1,4$, or $8 \% \mathrm{w} / \mathrm{w})$. The gas-filled pore volume of the system was calculated and the gas amendment (Table 1) was injected at $50 \mathrm{~mL} / \mathrm{min}$ for 18 minutes as the baseline injection approach. For one set of treatments the injection flow rate and time were adjusted to achieve the same mass of each gas amendment within the specified contact time (Table 1). Amended soil columns were then sealed and incubated for 3 weeks. For some cases, soil columns were then opened to air for 3 weeks. Each treatment included replicates so that sediment samples could be used to determine the Tc-99 concentration for 1) pre-treatment, 2) post-treatment, and 3) for selected treatments, after exposure of treated sediments to air for 3 weeks. Sequential liquid extractions at a 2:1 solution:sediment ratio were used to evaluate the distribution of Tc-99 in functionally defined pore-water and sediment fractions (Szecsody et al. 2014b, Table 2). This type of sequential extraction evaluation has previously been applied for investigation of uranium treatment (Szecsody et al. 2010a, b, 2012). Tc-99 concentration in the extraction solution was determined by scintillation counting.

Soil column leaching tests were conducted with selected treatments (Table 1) to quantify changes in Tc-99 mobility caused by the gas-phase amendments. Sediments $(<4 \mathrm{~mm})$ were packed into $0.75-\mathrm{cm}-$ diameter by 12-cm-long soil columns. High-performance liquid chromatography pumps were used to inject simulated groundwater upward through the vertically mounted soil column with a residence time of about $0.25 \mathrm{~h}$. Flow continued for 30 to 45 pore volumes. Effluent was collected using a fraction collector and samples were analyzed for Tc-99 at selected time intervals using scintillation counting. 
Table 1. Experimental matrix.

\begin{tabular}{|c|c|c|c|c|c|c|}
\hline Gas $(\%)$ & $\begin{array}{l}\text { Sequential } \\
\text { (S) } \\
\text { Parallel (P) }\end{array}$ & $\begin{array}{c}\text { Gas } \\
\text { Injection } \\
\text { Time }(\mathrm{h}) \\
\text { [reaction } \\
\text { time } 500 \mathrm{~h}]\end{array}$ & $\begin{array}{l}\text { Air Injection } \\
\text { Reaction Time } \\
\text { (h) }\end{array}$ & Tc-99 Conc. (pCi/g) & $\begin{array}{c}\text { Soil } \\
\text { Moisture } \\
\text { Content } \\
(\mathrm{g} / \mathrm{g})\end{array}$ & $\begin{array}{c}\text { Soil } \\
\text { Column } \\
\text { Leaching } \\
(\mathrm{Y} \text { or } \mathrm{N})\end{array}$ \\
\hline untreated & NA & -- & -- & $34,82,151,1978$ & 1,4 & $\mathrm{Y}$ \\
\hline $1 \% \mathrm{H}_{2} \mathrm{~S}$ & NA & 0.17 & none, 670 & 34 & 4 & $\mathrm{~N}$ \\
\hline $10 \% \mathrm{H}_{2} \mathrm{~S}$ & NA & 0.17 & none & 34 & 4 & $\mathrm{~N}$ \\
\hline $30 \% \mathrm{H}_{2} \mathrm{~S}$ & NA & 0.17 & none & 34 & 4 & $\mathrm{~N}$ \\
\hline $100 \% \mathrm{H}_{2} \mathrm{~S}$ & NA & 0.17 & none & 34 & 4 & $\mathrm{~N}$ \\
\hline $5 \% \mathrm{NH}_{3}$ & NA & 0.17 & none, 670 & 34 & 4 & $\mathrm{~N}$ \\
\hline $50 \% \mathrm{NH}_{3}$ & NA & 0.17 & none, 670 & 34 & 4 & $\mathrm{~N}$ \\
\hline $\begin{array}{c}1 / 5 \% \\
\mathrm{H}_{2} \mathrm{~S} / \mathrm{NH}_{3}\end{array}$ & $\mathrm{~S}, \mathrm{P}$ & 0.17 & none, 500 & 34 & 4 & $\mathrm{~N}$ \\
\hline $\begin{array}{c}1 / 5 \% \\
\mathrm{H}_{2} \mathrm{~S} / \mathrm{NH}_{3}\end{array}$ & $\mathrm{~S}, \mathrm{P}$ & 0.17 & none, 500 & 34 & 4 & $\mathrm{~N}$ \\
\hline $\begin{array}{c}3 / 10 \% \\
\mathrm{H}_{2} \mathrm{~S} / \mathrm{NH}_{3}\end{array}$ & $\mathrm{~S}, \mathrm{P}$ & 0.17 & none, 500 & 34 & 4 & $\mathrm{~N}$ \\
\hline $\begin{array}{c}10 / 10 \% \\
\mathrm{H}_{2} \mathrm{~S} / \mathrm{NH}_{3}\end{array}$ & $\mathrm{~S}, \mathrm{P}$ & 0.17 & none, 500 & 34,3000 & 4 & $\mathrm{Y}$ \\
\hline $\begin{array}{c}20 / 10 \% \\
\mathrm{H}_{2} \mathrm{~S} / \mathrm{NH}_{3}\end{array}$ & $\mathrm{~S}, \mathrm{P}$ & 0.17 & none, 500 & 34,3600 & 4 & $\mathrm{Y}$ \\
\hline $\begin{array}{c}50 / 50 \% \\
\mathrm{H}_{2} \mathrm{~S} / \mathrm{NH}_{3}\end{array}$ & $\mathrm{P}$ & 0.17 & none, 500 & 34 & 4 & $\mathrm{~N}$ \\
\hline $\begin{array}{l}10 / 100 \% \\
\mathrm{H}_{2} \mathrm{~S} / \mathrm{NH}_{3}\end{array}$ & $\mathrm{~S}$, & 0.17 & none & 34 & 4 & $\mathrm{~N}$ \\
\hline $\begin{array}{c}10 / 10 \% \\
\mathrm{H}_{2} \mathrm{~S} / \mathrm{NH}_{3}\end{array}$ & $\mathrm{P}, \mathrm{S}$ & $\begin{array}{c}0.017,0.17 \\
1.67,16\end{array}$ & 500 & 82 & 4 & $\mathrm{~N}$ \\
\hline $\begin{array}{c}10 / 10 \% \\
\mathrm{H}_{2} \mathrm{~S} / \mathrm{NH}_{3}\end{array}$ & $\mathrm{P}, \mathrm{S}$ & 0.17 & 500 & $\begin{array}{c}34,120,410,1328 \\
3870\end{array}$ & 4 & $\mathrm{~N}$ \\
\hline $\begin{array}{c}20 / 10 \% \\
\mathrm{H}_{2} \mathrm{~S} / \mathrm{NH}_{3}\end{array}$ & $\mathrm{P}$ & 0.17 & 500 & 3000 at $\mathrm{pH} 1.0$ & 4 & $\mathrm{~N}$ \\
\hline $\begin{array}{c}20 / 10 \% \\
\mathrm{H}_{2} \mathrm{~S} / \mathrm{NH}_{3}\end{array}$ & $\mathrm{P}$ & 0.17 & 500 & 3000 at pH 13. & 4 & $\mathrm{~N}$ \\
\hline $\begin{array}{c}20 / 10 \% \\
\mathrm{H}_{2} \mathrm{~S} / \mathrm{NH}_{3}\end{array}$ & $\mathrm{P}, \mathrm{S}$ & 0.17 & none, 500 & 3000 & $1,4,8$ & $\mathrm{~N}$ \\
\hline
\end{tabular}


Table 2. Sequential extraction solutions.

\begin{tabular}{|c|c|c|c|}
\hline Extraction Solution & $\begin{array}{l}\text { Hypothesized Targeted } \\
\text { Sediment Components }\end{array}$ & $\begin{array}{c}\text { Interpreted Tc-99 Mobility of } \\
\text { Extracted Fraction }\end{array}$ & $\begin{array}{l}\text { Color } \\
\text { Code }\end{array}$ \\
\hline $\begin{array}{l}\text { 1. Aqueous: } \\
\text { uncontaminated } \\
\text { Hanford } \\
\text { groundwater }\end{array}$ & $\begin{array}{l}\text { Tc-99 in pore water and a } \\
\text { portion of sorbed uranium }\end{array}$ & Mobile phase & \\
\hline $\begin{array}{l}\text { 2. Ion Exch.: } \\
0.5 \mathrm{M} \mathrm{Mg}\left(\mathrm{NO}_{3}\right)_{2}(1 \\
\text { h) }\end{array}$ & Readily desorbed Tc-99 & $\begin{array}{l}\text { Readily mobile through } \\
\text { equilibrium partitioning }\end{array}$ & \\
\hline $\begin{array}{l}\text { 3. Acetate } \mathrm{pH} 5: 1 \text { hour } \\
\text { in } \mathrm{pH} 5 \text { sodium } \\
\text { acetate solution }\end{array}$ & $\begin{array}{l}\text { Tc-99 associated with } \\
\text { surface exposed carbonate } \\
\text { precipitates or other readily } \\
\text { dissolved precipitates }\end{array}$ & $\begin{array}{l}\text { Moderately mobile through } \\
\text { rapid dissolution processes }\end{array}$ & \\
\hline $\begin{array}{l}\text { 4. Acetate } \mathrm{pH} 2.3 \text { : } \\
5 \text { days in } \mathrm{pH} 2.3 \\
\text { acetic acid }\end{array}$ & $\begin{array}{l}\text { Dissolution of most } \\
\text { carbonate compounds that } \\
\text { may coat Tc-99 }\end{array}$ & $\begin{array}{l}\text { Slow dissolution processes for } \\
\text { Tc-99 release from this fraction; } \\
\text { mobility is moderate to low with } \\
\text { respect to impacting } \\
\text { groundwater }\end{array}$ & \\
\hline $\begin{array}{l}\text { 5. Oxalic acid } \\
0.1 \mathrm{M} \text { ammonium } \\
\text { oxalate, } 0.1 \mathrm{M} \text { oxalic } \\
\text { acid }(1 \mathrm{~h})\end{array}$ & Dissolution of iron oxides & $\begin{array}{l}\text { Slow dissolution processes for } \\
\text { Tc- } 99 \text { release from this fraction; } \\
\text { mobility is low with respect to } \\
\text { impacting groundwater }\end{array}$ & \\
\hline $\begin{array}{l}\text { 6. } 8 \mathrm{M} \mathrm{HNO}_{3}: 2 \text { hours } \\
\text { in } 8 \mathrm{M} \text { nitric acid at } \\
95^{\circ} \mathrm{C}\end{array}$ & $\begin{array}{l}\text { Considered to represent } \\
\text { total Tc-99 extraction for } \\
\text { this study }\end{array}$ & $\begin{array}{l}\text { Very slow dissolution processes } \\
\text { are associated with Tc- } 99 \\
\text { release; functionally immobile }\end{array}$ & \\
\hline
\end{tabular}

\subsection{Results}

A series of experiments were conducted to evaluate the effectiveness and robustness of gas-phase treatment for Tc-99 using hydrogen sulfide and ammonia. The primary results of these tests are presented in this section, including use of pre- and post-treatment sequential sediment extraction of Tc-99 (Section 3.0) to evaluate treatment effectiveness as a function of 1) individual gas treatment for hydrogen sulfide and ammonia, 2) sequential and parallel injection of hydrogen sulfide and ammonia gases, 3) variations in gas concentrations, 4) variations in gas delivery time, 5) variations in sediment moisture content, and 6) variations in Tc-99 concentration. Soil column leaching test data for treated and untreated sediments are also presented as a more direct measure of how treatment changes the mobility of Tc-99. Additional details of this investigation are presented by Szecsody et al. (2014b).

As shown in Figure 2, individual treatments using hydrogen sulfide gas or ammonia vapor are not expected to be effective for decreasing Tc-99 mobility. Figure 3 shows the results of individual gas treatment tests. As expected, hydrogen sulfide decreased Tc-99 mobility when samples were maintained under anaerobic conditions, as indicated by the large decrease in mobile Tc-99 fractions and the increase in less mobile fractions (Section 3.0, Table 2) for post-treatment sequential extraction data compared to pre-treatment conditions. Once exposed to air, however, Tc-99 mobility returned to near pre-treatment conditions. Only moderate changes in the distribution of Tc-99 among sequential extraction fractions 
were observed with ammonia treatment, such that there would be minimal impact on overall Tc-99 mobility.
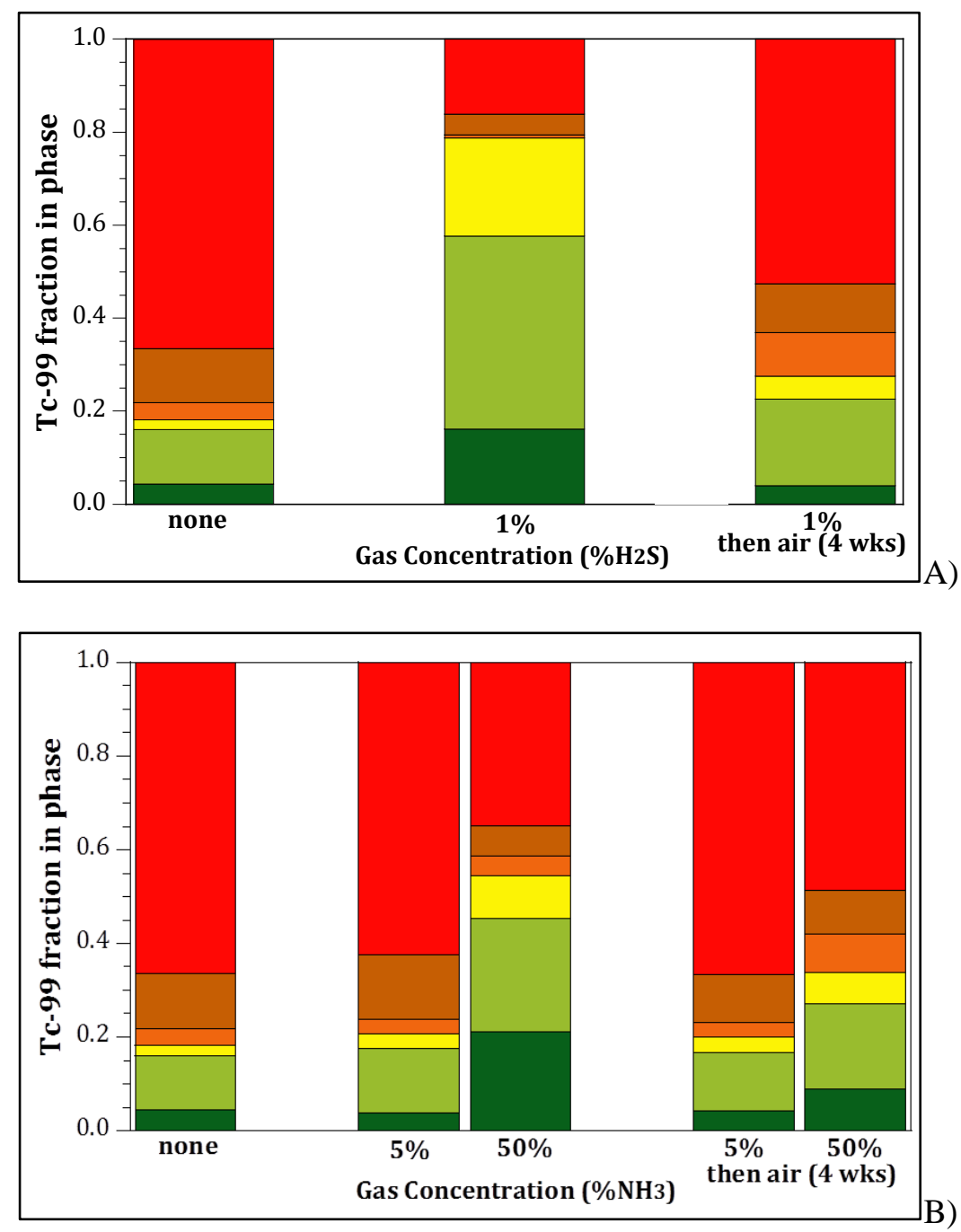

Figure 3. Sequential extraction data (Section 3.0, see Table 2 for color codes) for hydrogen sulfide (A) and ammonia (B) treatment of Tc-99-contaminated sediments in comparison to pre-treatment sequential extraction data (data element on left side). Sediment Tc-99 concentration was $82 \mathrm{pCi} / \mathrm{g}$.

A wide range of variations in treatment gas addition and sediment conditions were tested, as illustrated in Figure 4 through Figure 7. Additional details of the experiments and results are discussed by Szecsody et al. (2014b). Sequential (hydrogen sulfide, then ammonia) and parallel addition of hydrogen sulfide and ammonia gases were tested for a range of treatment gas concentrations (1 to $20 \%$ hydrogen sulfide and 5 to $10 \%$ ammonia). Consistent results for decreasing Tc-99 mobility were obtained when the hydrogen sulfide gas concentration was above $1 \%$ (Figure 4). These tests are not comprehensive in determining the best gas mixture for field application, but demonstrate robust treatment for a variety of gas concentration and delivery options. Additional laboratory testing was conducted with both parallel and sequential gas addition and a gas concentration of $10 \%$ for both hydrogen sulfide and 
ammonia. However, parallel addition may be a preferred approach for injection of gases into the subsurface in the field.

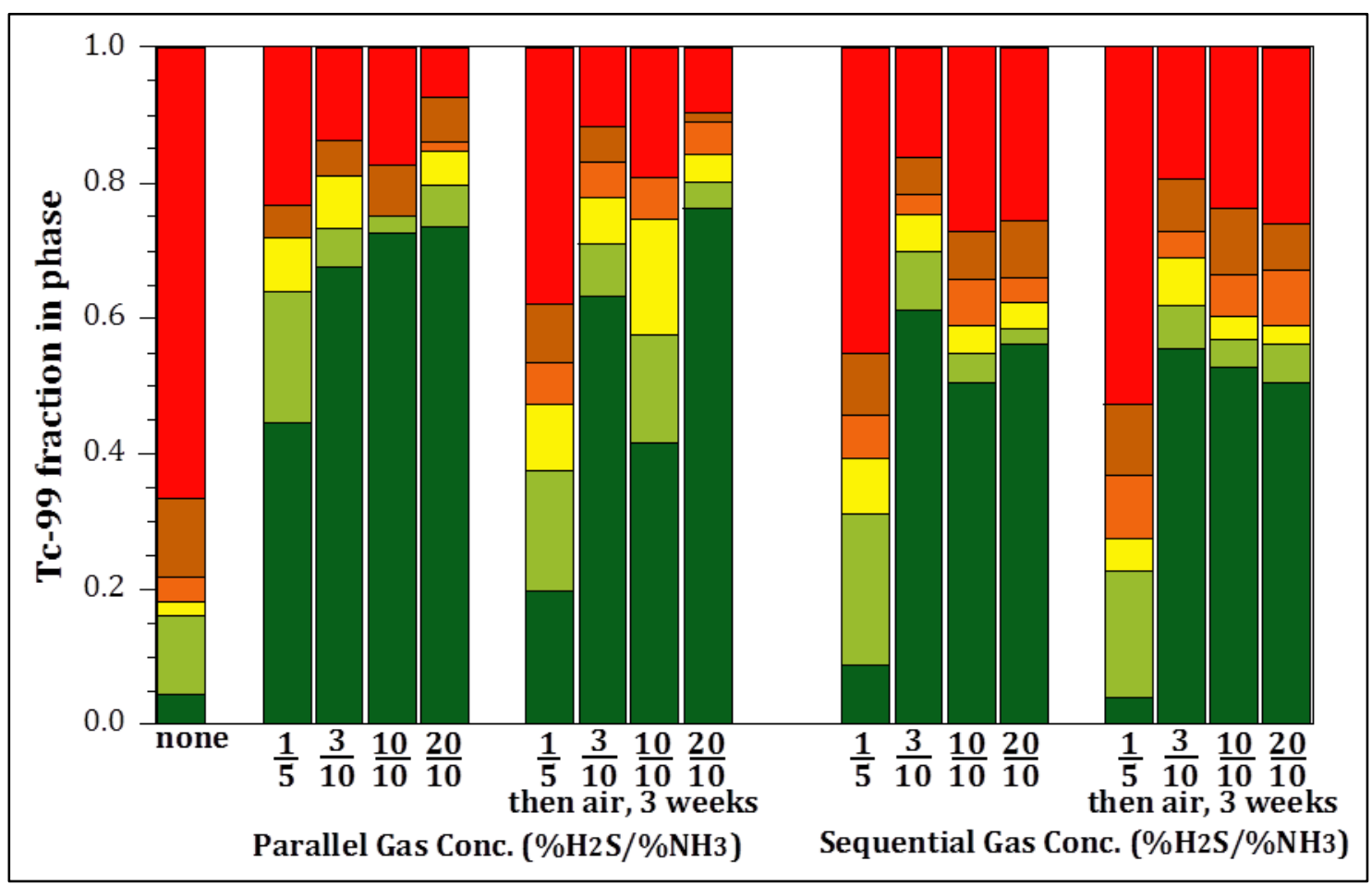

Figure 4. Sequential extraction data (Section 3.0, see Table 2 for color codes) for combined-gas treatment using sequential (hydrogen sulfide, then ammonia) or parallel gas addition over a range of gas concentrations. Results show data before treatment, after treatment, and after treatment plus oxidation by air addition for 3 weeks. The sediment Tc-99 concentration was $82 \mathrm{pCi} / \mathrm{g}$.

The Tc-99 concentration may vary significantly at targeted treatment zones in the vadose zone of the Hanford Central Plateau. Experiments conducted using existing and spiked Tc-99 concentrations to obtain concentrations ranging from 34 to $3800 \mathrm{pCi} / \mathrm{g}$ showed only small variations in the ability of the applied gas treatment to decrease Tc-99 mobility, even after oxidation of the post-treatment samples (Figure 5). This result is important in that it suggests that a sufficient amount of stable precipitates is formed to cover surface-associated Tc-99 and make it resistant to reoxidation and mobilization for the tested conditions covering a wide range of initial Tc-99 concentrations. Site-specific evaluation for highconcentration Tc-99 zones may be needed to verify the effectiveness of the treatment. For vadose zone treatment, it may not be necessary to immobilize all of the Tc-99 at a site. Rather, remediation targets can be evaluated in terms of immobilizing a sufficient portion of the Tc-99 contamination to keep the Tc-99 flux to the groundwater below levels of concern. 


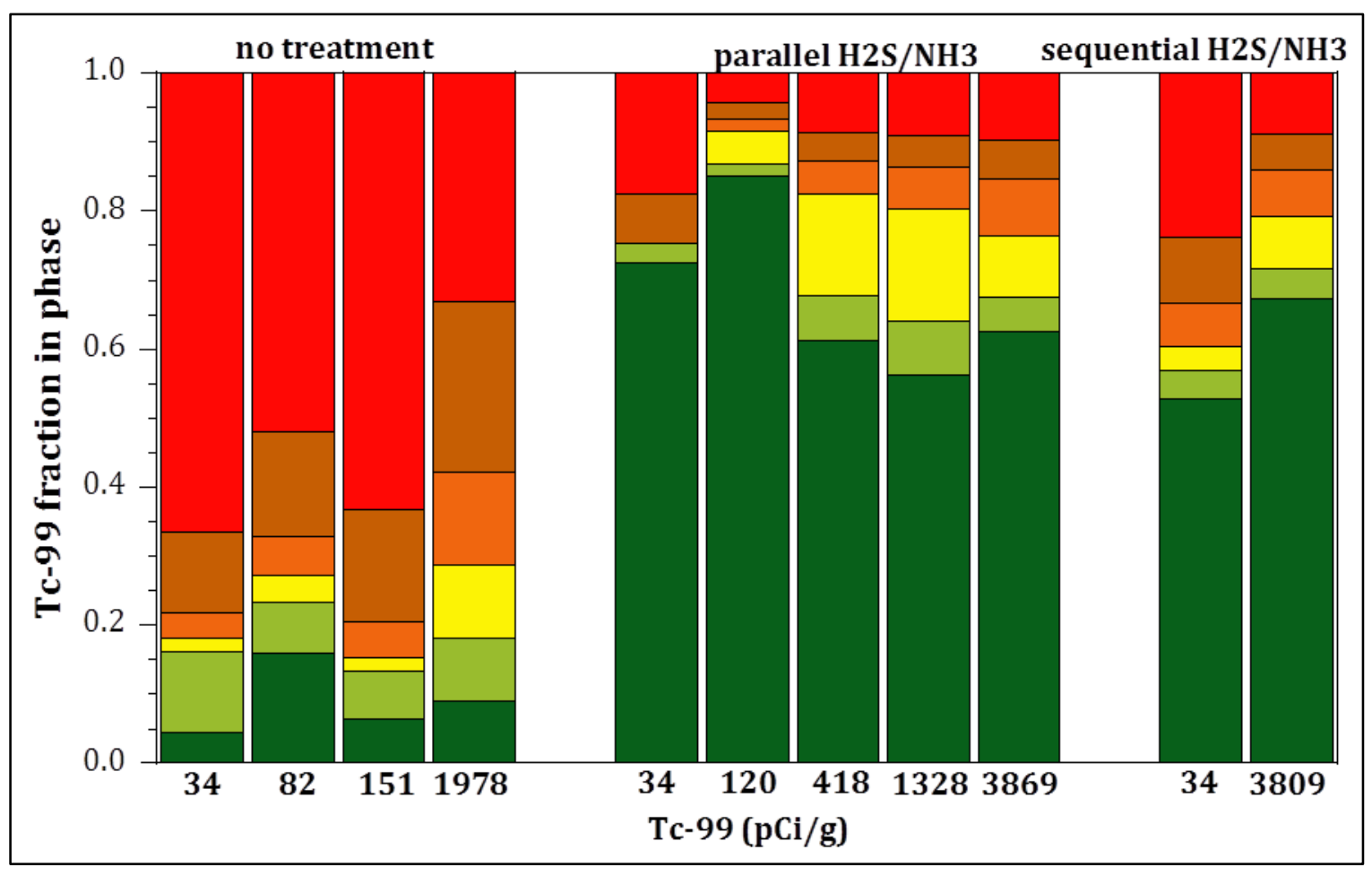

Figure 5. Sequential extraction data (Section 3.0, see Table 2 for color codes) for combined-gas treatment using sequential (hydrogen sulfide, then ammonia) or parallel gas addition over a range of Tc-99 sediment concentrations. Results show data before treatment and after treatment and oxidation by air addition for 3 weeks. A $10 \%$ concentration was used for both hydrogen sulfide and ammonia gases.

Variations in the sediment moisture content at Tc-99-contaminated sites are expected. Experiments examining soil moisture contents of 1,4 , and $8 \mathrm{wt} \%$ showed only minor variation in the ability of the applied gas treatment to decrease Tc-99 mobility, even after oxidation of the post-treatment samples (Figure 6). These results suggest that the treatment effectiveness is not impacted across the range of tested moisture contents for the sediments used in the experiments. Testing may be needed at a specific site with respect to variations in sediment type that may lead to associated differences in sediment moisture content. 


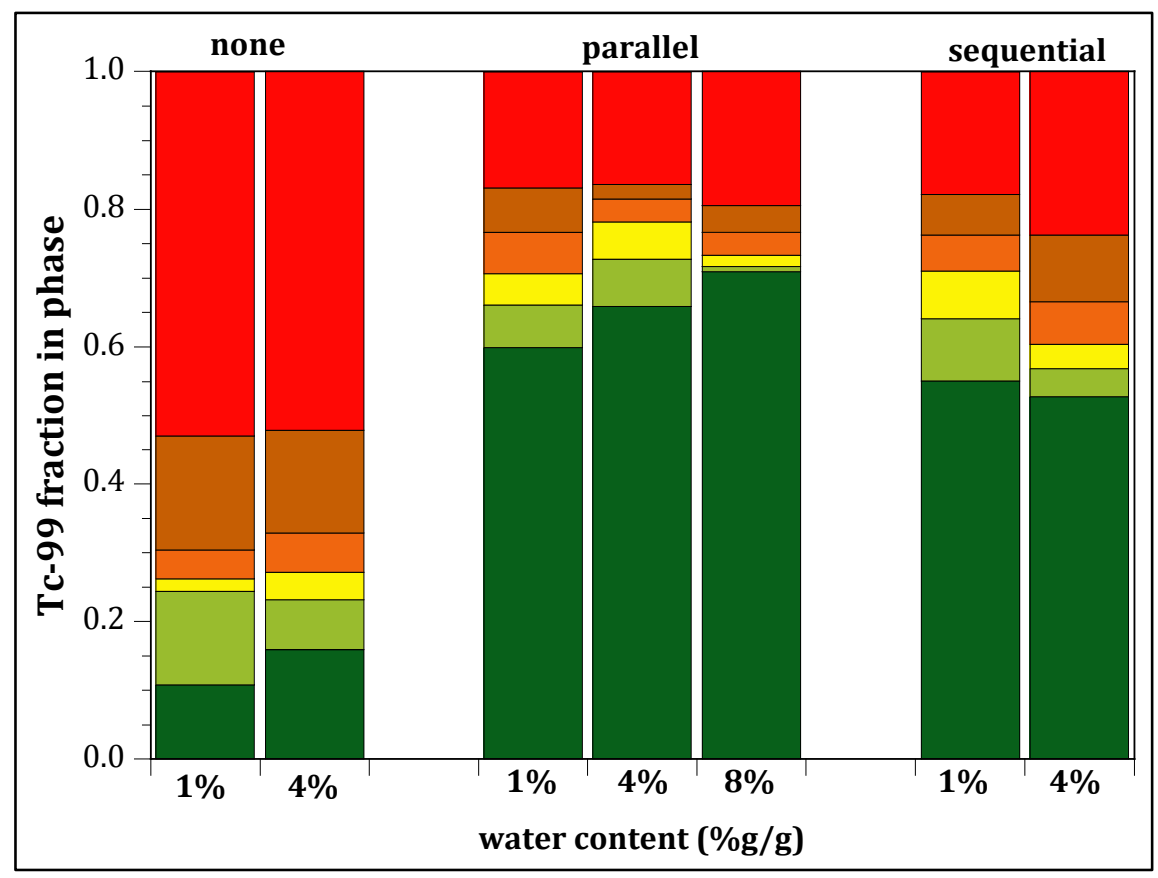

Figure 6. Sequential extraction data (Section 3.0, see Table 2 for color codes) for combined-gas treatment using sequential (hydrogen sulfide, then ammonia) or parallel gas addition for different soil moisture content values. Results show data before treatment and after treatment and oxidation by air addition for 3 weeks. A $10 \%$ concentration was used for both hydrogen sulfide and ammonia gases. The sediment Tc-99 concentration was $82 \mathrm{pCi} / \mathrm{g}$.

With gas injection through a well screen, sediments will be exposed to the gases for varying amounts of time as a function of gas-flow patterns, with generally decreasing contact time as a function of radial distance from the well or as a function of the diffusion scale from main advective pathways of gas transport. Experiments examining times for gas delivery into the sample ranging from minutes to hours showed only minor variations in the ability to decrease Tc-99 mobility (Figure 7). These results confirm the rapid partitioning of the gases into the pore water to initiate the treatment processes. Thus, field gas injection design would primarily focus on obtaining the target gas amendment distribution and would not need to consider gas contact time. 


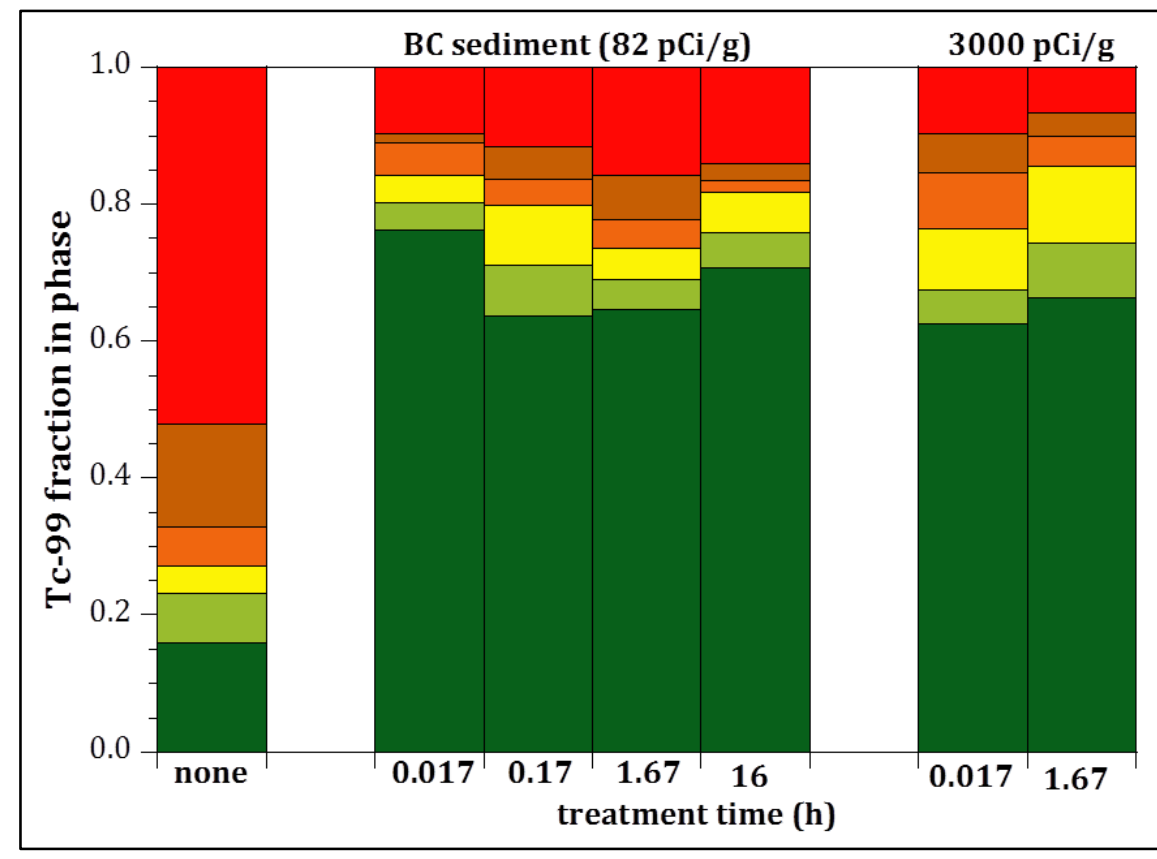

Figure 7. Sequential extraction data (Section 3.0, see Table 2 for color codes) for combined-gas treatment using parallel gas addition over a range of minutes to hours for the gas delivery into the sample. Results show data before and after treatment with no oxidation. A $10 \%$ concentration was used for both hydrogen sulfide and ammonia gases. The sediment Tc-99 concentration was $82 \mathrm{pCi} / \mathrm{g}$ (present in the sample) or spiked to $3000 \mathrm{pCi} / \mathrm{g}$.

The sequential extraction procedure provides data that can be interpreted in terms of Tc-99 mobility (see Section 3.0 and Szecsody et al. 2010a, b, 2012, 2013, 2014b). Saturated soil column leaching tests are another widely applied method used to evaluate the mobility of contaminants in sediments and this approach has been previously applied to evaluate the leaching of contaminants at the Hanford Site (e.g., Szecsody et al. 2013, 2014b; Qafoku et al. 2009). Saturated soil column leaching experiments with contaminated Hanford Site sediments were conducted for pre-treatment sediment samples and with posttreatment sediments that had been exposed to either parallel or sequential treatment. The results confirm that the Tc-99 associated with the mobile and moderately mobile fractions in sequential extractions are leached from the sediments and carried to the effluent of the soil column (Figure 8). Thus, the cumulative mass of Tc-99 eluted from the soil columns for the treated sediment was about an order of magnitude lower than for the untreated sediment after 40 pore volumes of leaching. Sequential extractions of postleached sediments showed that only functionally immobile Tc-99 remained on the sediment at the end of the leaching experiment, suggesting that further leaching would be minimal. Only minor differences in leaching results for sequential and parallel treatment were observed. 


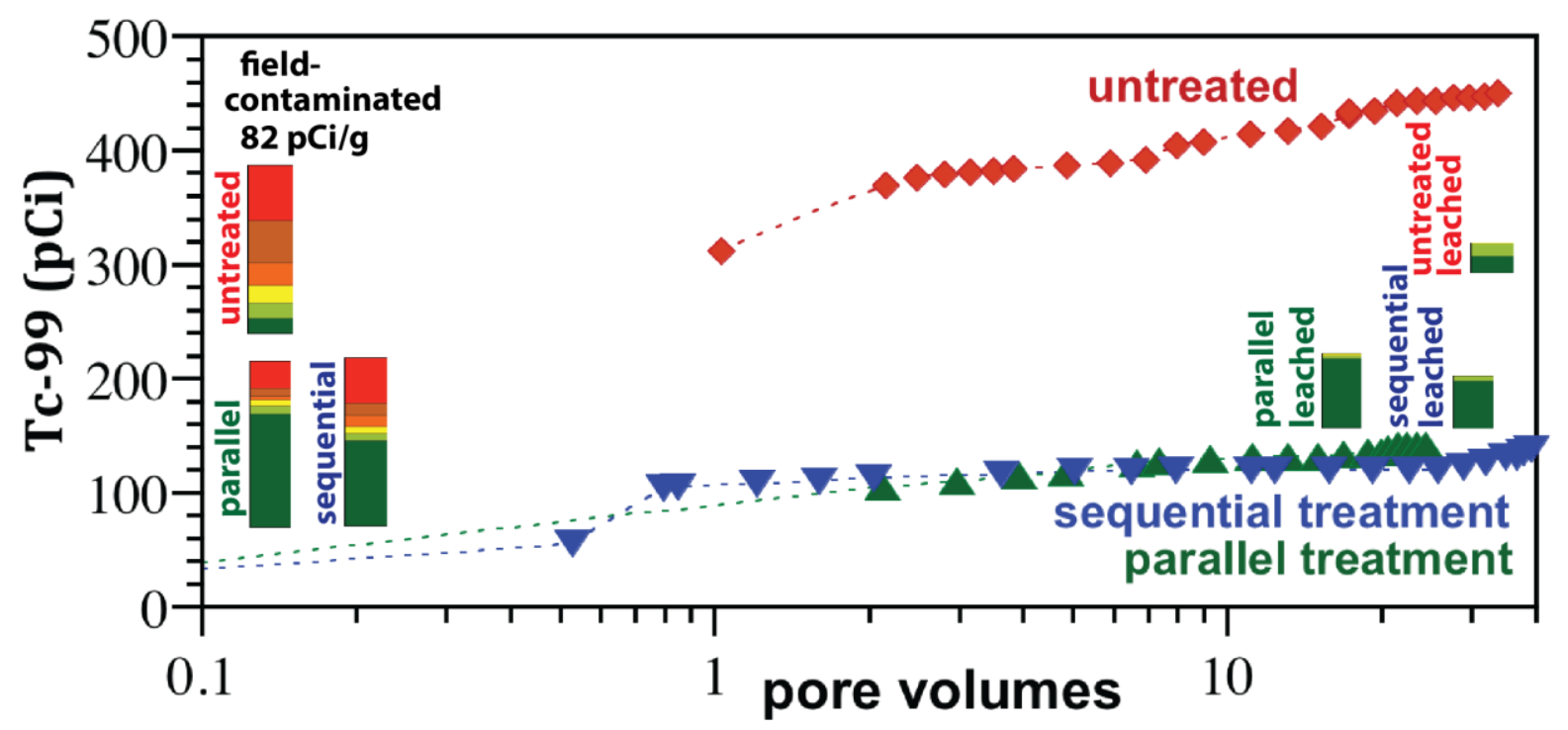

Figure 8. Saturated soil column leaching test results using sediment from the BC Cribs and Trenches site. Colored bars represent the relative amount of Tc-99 in the extractions defined in Table 2 for samples before and after leaching.

\subsection{Conclusions and Implications for Field Testing of the Technology}

A series of laboratory experiments were conducted that demonstrate a robust treatment approach to decrease the mobility of Tc-99 in the vadose zone at the Hanford Central Plateau using gas-phase amendments. The gas-phase Tc-99 treatment was shown to be effective with respect to variations including 1) sequential and parallel addition of hydrogen sulfide and ammonia gases over a range of treatment gas concentrations ( 1 to $20 \%$ hydrogen sulfide and 5 to $10 \%$ ammonia), 2) Tc-99 concentrations ranging from 34 to $3800 \mathrm{pCi} / \mathrm{g}, 3$ ) soil moisture contents of 1, 4, and $8 \mathrm{wt} \%$, and 4) gas delivery times into the sample ranging from minutes to hours. A large fraction of Tc-99 in treated sediments was also shown to be resistant to leaching in saturated soil column tests. These laboratory results suggest that the combined hydrogen sulfide and ammonia gas treatment is a viable candidate for treatment of Tc-99 to decrease its mobility in the vadose zone.

The combined-gas Tc-99 treatment technique is an extension of the ammonia gas treatment for uranium. Previous efforts have examined many aspects of the ammonia treatment process, including key information needed to scale this process to field application (Szecsody et al. 2010b, 2013; Zhong et al. 2014; Truex et al. 2014). Much of this scale-up information is applicable to field application of the combined hydrogen sulfide and ammonia gas treatment demonstrated in this study to decrease Tc-99 mobility. 
Several additional scale-up elements should be considered to support field testing of this technology. The fate and transport of hydrogen sulfide gas in the subsurface in the presence of ammonia gas is important with respect to larger scale distribution of the treatment gases such that appropriate gas concentrations for both gases reach targeted treatment zones. In addition, this fate and transport information can support evaluation of safe operational conditions for use of hydrogen sulfide. For instance, if hydrogen sulfide rapidly partitions and dissociates in the pore water, there is less chance of injected hydrogen sulfide moving to the ground surface. Oxidation of hydrogen sulfide in the subsurface should also be evaluated with respect to limiting the migration of the gas. Some additional information on the reaction rates and processes in relation to subsurface $\mathrm{pH}$ conditions and Tc-99 precipitate stability and whether microbial processes interact with these reactions will also be important.

While this study examined a range of hydrogen sulfide and ammonia gas concentrations, additional investigation to refine selection of appropriate gas concentrations may be important for designing effective treatment and for supporting operational, equipment, and safety designs for use in the field. Field application will also require engineering of appropriate equipment for safe injection operations. Monitoring of the treatment is also important, and minimizing collection of gas samples may be important for health and safety reasons. Thus, extension of the electrical resistivity tomography monitoring previously applied for soil desiccation (Truex et al. 2013) and researched for application to ammonia treatment of uranium (Szecsody et al. 2012; Truex et al. 2014) should be considered for the combined-gas treatment.

The study of combined-gas treatment has been limited to observing its effect on Tc-99 mobility. Other contaminants may be present at target treatment locations in the Hanford Central Plateau. Thus, investigating the potential positive and negative impacts of combined-gas treatment on likely cocontaminants may be needed. With respect to uranium co-contamination, the chemistry induced by the combined hydrogen sulfide and ammonia gas treatment would be expected to have similar or better effectiveness for decreasing uranium mobility than the ammonia gas treatment. Like Tc-99, uranium can be geochemically reduced and will subsequently precipitate. The reduced, precipitated uranium may be more amenable to coating by stable aluminosilicates than oxidized uranium species that are prevalent in the Hanford vadose zone, thereby improving the effectiveness of uranium treatment. However, this hypothesis needs to be evaluated.

\subsection{Quality Assurance}

The PNNL Quality Assurance (QA) Program is based upon the requirements defined in DOE Order 414.1D, Quality Assurance and 10 CFR 830, Energy/Nuclear Safety Management, Subpart A - Quality Assurance Requirements (a.k.a. the Quality Rule). PNNL has chosen to implement the following consensus standards in a graded approach:

- ASME NQA-1-2000, Quality Assurance Requirements for Nuclear Facility Applications, Part 1, Requirements for Quality Assurance Programs for Nuclear Facilities.

- ASME NQA-1-2000, Part II, Subpart 2.7, Quality Assurance Requirements for Computer Software for Nuclear Facility Applications, including problem reporting and corrective action. 
- ASME NQA-1-2000, Part IV, Subpart 4.2, Guidance on Graded Application of Quality Assurance (QA) for Nuclear-Related Research and Development.

The procedures necessary to implement the requirements are documented through PNNL's "How Do I...? (HDI) system, a system for managing the delivery of laboratory-level policies, requirements and procedures.

The DVZ-AFRI Quality Assurance Plan (Meier 2014) is the minimum applicable QA document for all Deep Vadose Zone-Applied Field Research Initiative (DVZ-AFRI) projects. This QA Plan also conforms to the QA requirements of DOE Order 414.1D, Quality Assurance, and 10 CFR 830, Subpart A, Quality Assurance Requirements. The DVZ-AFRI is subject to the Price Anderson Amendments Act. The implementation of the DVZ-AFRI quality assurance program is graded in accordance with NQA-12000, Part IV, Subpart 4.2, Guidance on Graded Application of Quality Assurance (QA) for NuclearRelated Research and Development.

The work for this report was performed under the technology level of Applied Research. Applied Research consists of research tasks that acquire data and documentation necessary to ensure satisfactory reproducibility of results. The emphasis during this stage of a research task is on achieving adequate documentation and controls necessary to be able to reproduce results. 


\subsection{References}

10 CFR 830, Subpart A, 2001 - “Quality Assurance Requirements.” U.S. Code of Federal Regulations.

ASME (The American Society of Mechanical Engineers) 2001. Quality Assurance Requirements for Nuclear Facility Applications. NQA-1-2000, New York, New York.

Burke I, C Boothman, F Liens, J Charnock, J McBeth, R Mortimer, and K Morris. 2006. "Reoxidation behavior of technetium, iron, and sulfur in estuarine sediments." Environmental Science and Technology 40:3529-3535.

Denham, ME and BB Looney. 2007. “Gas: A Neglected Phase in Remediation of Metals and Radionuclides.” Environmental Science and Technology 41(12):4193-4198.

DOE (U.S. Department of Energy). 2011, as amended. DOE Order 414.1D, Quality Assurance. Washington, D.C.

DOE/RL (U.S. Department of Energy/Richland Operations Office). 2008. Deep Vadose Zone Treatability Test Plan for the Hanford Central Plateau. DOE/RL-2007-56, Revision 0, Richland, Washington.

Dresel PE, DM Wellman, KJ Cantrell, and MJ Truex. 2011. "Review: Technical and Policy Challenges in Deep Vadose Zone Remediation of Metals and Radionuclides." Environmental Science and Technology 45(10):4207-4216.

Fayer MJ, AL Ward, and VL Freedman. 2010. Technical Basis for Evaluating Surface Barriers to Protect Groundwater from Deep Vadose Zone Contamination. PNNL-18661, Pacific Northwest National Laboratory, Richland, Washington.

Jansik D, J Istok, J Szecsody, D Wellman, and J McKinley. 2014. "Influence of discharged waste chemistry on the geochemical retention of Tc in vadose zone sediments." In preparation for Chemosphere.

Meier, KM. 2014. Deep Vadose Zone Applied Field Research Initiative Quality Assurance Plan. QADVZ-AFRI-001, Rev. 1, Pacific Northwest National Laboratory, Richland, Washington.

PAAA-Price-Anderson Amendments Act. Energy Policy Act of 2005. Title VI-Nuclear Matters, Subtitle A-Price-Anderson Act Amendments, Section 601 et. seq. Public Law 109-58, as amended. 42 USC 15801 et seq.

Qafoku NP, PE Dresel, JP McKinley, C Liu, SM Heald, CC Ainsworth, JL Phillips, and JS Fruchter. 2009. "Pathways of Aqueous Cr(VI) Attenuation in a Slightly Alkaline Oxic Subsurface."

Environmental Science and Technology 43:1071-1077.

Szecsody JE, D Jansik, JP McKinley, and N Hess. 2014a. "Influence of alkaline waste on technetium mobility in Hanford formation sediments." Journal of Environmental Radioactivity 135:147-160. 
Szecsody, JE, L Zhong, MJ Truex, and N Qafoku. 2014b. "Remediation of technetium in the vadose zone using reactive gasses NH3 and H2S." Submitted to Vadose Zone Journal.

Szecsody JE, MJ Truex, N Qafoku, DM Wellman, T Resch, and L Zhong. 2013. "Influence of acidic and alkaline waste solution properties on uranium migration in subsurface sediments." Journal of Contaminant Hydrology 151:155-175. dx.doi.org/10.1016/j.jconhyd.2013.05.009.

Szecsody JE, MJ Truex, L Zhong, TC Johnson, NP Qafoku, MD Williams, JW Greenwood, EL Wallin, JD Bargar, and DK Faurie. 2012. "Geochemical and Geophysical Changes During $\mathrm{NH}_{3}$ Gas Treatment of Vadose Zone Sediments for Uranium Remediation.” Vadose Zone Journal 11(4).

DOI: $10.2136 /$ vzj2011.0158.

Szecsody JE, MJ Truex, L Zhong, NP Qafoku, MD Williams, JP McKinley, CT Resch, JL Phillips, D Faurie, and J Bargar. 2010a. Remediation of Uranium in the Hanford Vadose Zone Using Ammonia Gas: FY10 Laboratory-Scale Experiments. PNNL-20004, Pacific Northwest National Laboratory, Richland, Washington.

Szecsody JE, MJ Truex, L Zhong, MD Williams, and CT Resch. 2010b. Remediation of Uranium in the Hanford Vadose Zone Using Gas-Transported Reactants: Laboratory-Scale Experiments. PNNL-18879, Pacific Northwest National Laboratory, Richland, Washington.

Truex, MJ, JE Szecsody, L Zhong, JN Thomle, and TC Johnson. 2014. Scale-Up Information for GasPhase Ammonia Treatment of Uranium in the Vadose Zone at the Hanford Site Central Plateau. PNNL23699, Pacific Northwest National Laboratory, Richland, Washington.

Truex MJ, TC Johnson, CE Strickland, JE Peterson, and SS Hubbard. 2013. "Monitoring Vadose Zone Desiccation with Geophysical Methods.” Vadose Zone Journal 12(2). doi:10.2136/vzj2012.0147.

Truex M., M Oostrom, CE Strickland, GB Chronister, MW Benecke, and CD Johnson. 2012. "FieldScale Assessment of Desiccation Implementation for Deep Vadose Zone Contaminants." Vadose Zone Journal 11. DOI:10.2136/vzj2011.0144.

Truex MJ, M Oostrom, F Zhang, KC Carroll, J Schramke, TW Wietsma, GD Tartakovsky, and K Gordon. 2010a. Evaluation of Soil Flushing for Application to the Deep Vadose Zone in the Hanford Central Plateau. PNNL-19938, Pacific Northwest National Laboratory, Richland, Washington.

Truex MJ, EM Pierce, MJ Nimmons, and SV Mattigod. 2010b. Evaluation of In Situ Grouting as a Potential Remediation Method for the 200 Area Vadose Zone. PNNL-20051, Pacific Northwest National Laboratory, Richland, Washington.

Zachara J, S Heald, B Jeon, R Kukkadapu, C Liu, J McKinley, A Dohnalkova, and D Moore. 2007. "Reduction of Pertechnetate [Tc(VII)] by Aqueous Fe(II) and the Nature of Solid Phase Redox Products." Geochimica et Cosmochimica Acta 71:2137-2157.

Zhong L, NP Qafoku, JE Szecsody, PE Dresel, and ZF Zhang. 2009. "Foam Delivery of Calcium Polysulfide to Vadose Zone for Cr(VI) Immobilization - Laboratory Evaluation." Vadose Zone Journal 8(4). DOI:10.2136/vzj2008.0124. 
Zhong L, JE Szecsody, MJ Truex, and MD Williams. 2014. “Ammonia Gas Transport and Reactions in Unsaturated Sediments: Implications for Use as an Amendment for Immobilize Inorganic Contaminants." Submitted Journal of Hazardous Materials. 



\section{Distribution}

No. of

$\underline{\text { Copies }}$

2 U.S. Department of Energy/Richland Operations Office

Hardcopies:

Briant Charboneau

John Morse
No. of

\section{Copies}

Pacific Northwest National

Laboratory

MJ Truex

JE Szecsody

L Zhong

N Qafoku

DM Wellman
(PDF)

(PDF)

(PDF)

(PDF)

(PDF)

Distr.1 


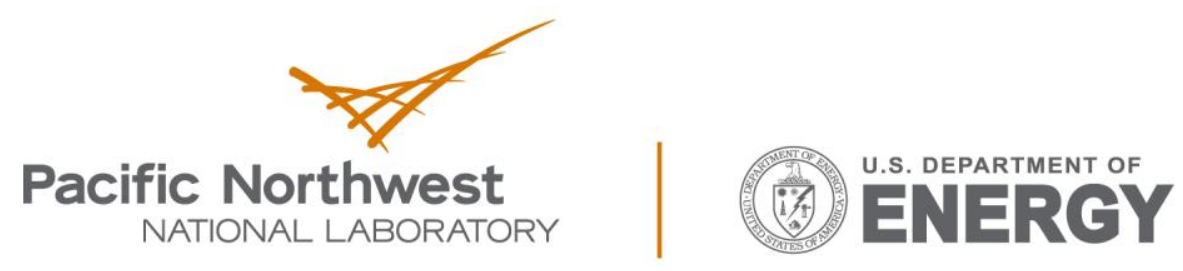

Proudly Operated by Battelle Since 1965

902 Battelle Boulevard

P.O. Box 999

Richland, WA 99352

1-888-375-PNNL (7665)

www.pnnl.gov 